\title{
Immunsystem
}

\section{Kuhmilch-Protein Beta-Laktoglobulin verhindert Allergien}

Zahlreiche Studien zeigen, dass sowohl das Aufwachsen auf einem Bauernhof als auch das Trinken von unverarbeiteter, natürlicher Kuhmilch in den ersten Lebensjahren vor der Entwicklung von Immunglobulinen E (IgE) schützt, die für allergische Symptome verantwortlich sind. In einer aktuellen Studie unter der Leitung von Dr. Franziska Roth-Walter und Prof. Dr. Erika Jensen-Jarolim vom Institut für Pathophysiologie und Allergieforschung der MedUni Wien und vom interuniversitären Messerli Forschungsinstitut konnte nun gezeigt werden, dass ein von Kühen abgesondertes Protein, Beta-Laktoglobulin, welches auch in der Milch vorkommt, ein Schlüsselmolekül für den so genannten Bauernhofschutz gegen Allergien darstellt.

Das bäuerliche Umfeld trainiert das Immunsystem. Kinder, die im Kuhstall spielen und unverarbeitete Milch trinken, leiden seltener unter Allergien und Asthma (• Abb. 1). Diesen Effekt nennt man Bauernhofschutz. In Laborund Tiermodellstudien zeigte ein Forscherteam, dass Beta-Laktoglobulin, wenn es seine natürlichen Liganden, wie Pflanzenpigmente aus grünem Gras, mit sich trägt, Allergien verhindert [1]. Im Gegensatz dazu verhielt sich das Protein ohne seine natürlichen Liganden wie ein Allergen.

\section{》) Ein bäuerliches Umfeld trainiert} das Immunsystem

Dr. Roth-Walter: „Die anti-allergischen Eigenschaften von natürlichem Beta-Laktoglobulin lassen sich damit erklären, dass dieses Protein seine Liganden gezielt zu den Immunabwehrzellen bringt und dadurch eine Entzündung verhindert wird. Die natürlichen Liganden verhindern außerdem, dass IgE-Antikörper an Beta-Laktoglobulin-Protein andocken können, wodurch diese von Milch-allergischen Kindern besser vertragen werden sollte."

\section{Neues Schlüsselmolekül}

Die Studie präsentiert daher mit dem Kuh-Protein Beta-Laktoglobulin ein neues Molekül, das zusammen mit seinen natürlichen Liganden für die Bauernhof-Schutzwirkung gegen Allergien von Interesse ist. Umstände, die zu einem Verlust oder einem Mangel dieser Liganden führen können, z.B. durch die industrielle Milchverarbeitung oder mangelhafte Tierfutterqualität, können das gut verträgliche Milchprotein Beta-Laktoglobulin allerdings in ein Allergen verwandeln. „Unsere Studie lässt hoffen, dass der Bauernhof-Allergieschutz-Effekt praktikabler gemacht und genutzt werden kann, um die Allergieepidemie zu verhindern", betont Prof. Dr. Erika JensenJarolim.

\section{Literatur}

1. Roth-Walter $\mathrm{F}$ et al (2020) Cow milk protein beta-lactoglobulin confers resilience against allergy by targeting complexed iron into immune cells. J Allergy Clin Immunol S00916749(20)30742-9. https://doi.org/10.1016/j. jaci.2020.05.023.

Hinweis des Verlags. Der Verlag bleibt in Hinblick auf geografische Zuordnungen und Gebietsbezeichnungen in veröffentlichten Karten und Institutsadressen neutral.

\section{hautnah $2020 \cdot 19: 113$}

https://doi.org/10.1007/s12326-02000400-y

(c) Springer-Verlag GmbH Austria, ein Teil von Springer Nature 2020

\section{Quelle: Presseaussen- dung Medizinische Universität Wien}

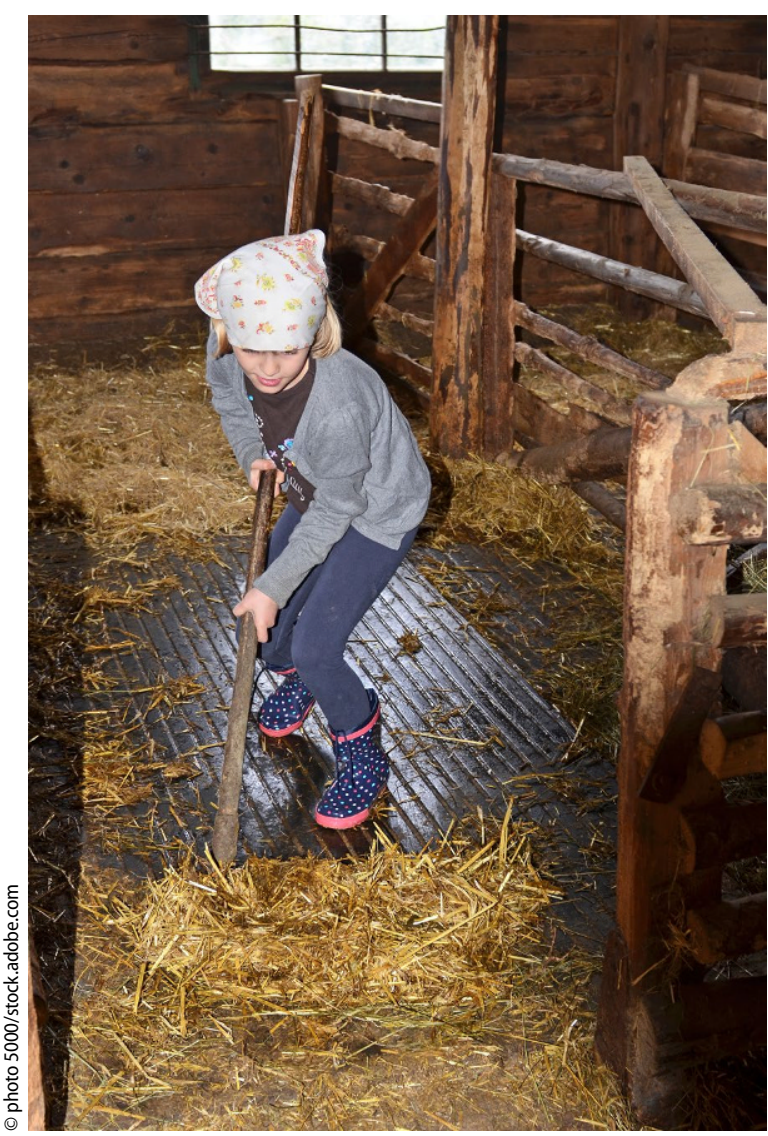

Abb. 1 ॥ Kinder, die im Kuhstall spielen und unverarbeitete Milch trinken, leiden seltener unter Allergien und Asthma. (Symbolbild mit Fotomodell) 